\title{
Grandisin caused morphological changes larval and toxicity on Aedes aegypti
}

\author{
Ana Carolina C. F. Leite, ${ }^{1}$ Massuo J. Kato, ${ }^{2}$ Renata O. A. \\ Soares, ${ }^{3}$ Anthony E. Guimarães, ${ }^{1}$ Jacenir R. Santos-Mallet, ${ }^{4}$ \\ Marise M. O. Cabral ${ }^{*}, 1,5$
}

${ }^{1}$ Laboratório de Diptera, Instituto Oswaldo cruz, Fundação Oswaldo Cruz, Brazil, ${ }^{2}$ Laboratório de Química de Produtos Naturais, Departamento de Química Fundamental, Instituto de Química, Universidade de São Paulo, Brazil,

${ }^{3}$ Laboratório de Bioquímica de Tripanosomatídeos, Instituto Oswaldo Cruz, Fundação Oswaldo Cruz, Brazil,

${ }^{4}$ Laboratório de Transmissores de Leishmanioses, Setor de Entomologia Médica e Forense, Instituto Oswaldo Cruz, Fundação Oswaldo Cruz, Brazil,

${ }_{5}^{5}$ Laboratório de Insetos Vetores, Unidade de Ensino, Pesquisa e Extensão Professor Antonio Orlando Izolani, Centro de Ciências Exatas, Tecnológicas e da Natureza, Universidade Severino Sombra, Brazil.

\begin{abstract}
Dengue is a tropical disease caused by an arbovirus transmitted by Aedes aegypti. Since no effective vaccine is available for treating dengue, the present study focused on population vector control through investigating the use of the lignan grandisin, isolated from Piper solmsianum C. DC., Piperaceae, against the larvae of A. aegypti. Grandisin caused larval (L3) mortality at LC50 $150 \mu \mathrm{g} / \mathrm{mL}$. Histological analysis on $A$. aegypti larvae treated with grandisin (LC50 $50 \mu \mathrm{g} / \mathrm{mL}$ ) showed changes in the anterior-middle midgut, with intense tissue destruction and cell disorganization.
\end{abstract}

Revista Brasileira de Farmacognosia Brazilian Journal of Pharmacognosy 22(3): 517-521, May/Jun. 2012

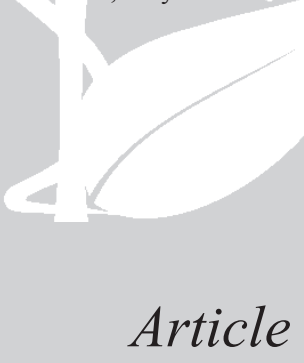

Received 21 Jun 2011

Accepted 27 Sep 2011

Available online 24 Jan 2012

Keywords:

Aedes aegypti

Piper solmsianum

histology

toxicity

tropical disease

ISSN 0102-695X http://dx.doi.org/10.1590/S0102$695 \times 2012005000016$

\section{Introduction}

The species Piper solmsianum C. DC. belongs to the Piperaceae family and is an endemic species from the Atlantic Forest (Mata Atlântica) in Brazil (QuijanoAbril et al., 2006). Secondary metabolism in most of the Piperaceae species appears to be restricted to the production of only a few classes of compounds such as amides, lignans and neolignans (Martins et al., 2000; Kato \& Furlan, 2007). Several studies have been carried out on lignans and their effects on insects (Cabral et al., 2000 a,b; Cabral et al. 2001). The tetrahydrofuran lignan grandisin has been described as the major secondary metabolite in the leaves of $P$. solmsianum (Martins et al., 2003) and was first isolated from Litsea grandis (Holloway \& Scheinmann, 1974). This substance has displayed powerful trypanocidal activity (Lopes et al., 1998; Kato \& Furlan 2007) disruption of insect growth activity (Nogueira et al., 2009) and larvicidal activity (Cabral et al., 2009). Aedes (Stegomyia) aegypti L., 1762 (Diptera: Culicidae) is a widely distributed Neotropical species and it is the main vector insect for dengue disease (Consoli \& Oliveira, 1994). Thus, the aim of this study was to determine the cytotoxicity and digestive system morphological changes of grandisin against immature forms (L3) of A. aegypti.

\section{Material and Methods}

(-)-Grandisin (1) was obtained from dried inflorescences of $P$. solmsianum that was collected from a garden at the Institute of Chemistry, USP, São Paulo (Martins et al., 2000). A sample, isolated as previously described (Martins et al., 2003) was dissolved in acetone and diluted at $1: 4$ in $0.8 \% \mathrm{NaCl}$ at concentrations of $1-200 \mu \mathrm{g} / \mathrm{mL}$. A. aegypti eggs were obtained from the Transmissores de Hematozoários Laboratory, Instituto Oswaldo Cruz, FIOCRUZ, and a colony was maintained in the Diptera Laboratory, Instituto Oswaldo Cruz, Rio de Janeiro. All experiments were carried out on third-instar (L3) larvae (F1-F5).<smiles>COc1cc([C@H]2O[C@H](c3cc(OC)c(OC)c(OC)c3)[C@H](C)[C@@H]2C)cc(OC)c1OC</smiles>

The grandisin solution $(\mu \mathrm{g} / \mathrm{mL})$ was applied to the Petri dishes $(9.0 \times 2.0 \mathrm{~cm})$, which contained dechlorinated water $(5 \mathrm{~mL})$ at 5, 30, 50, 100 and $200 \mu \mathrm{g} /$ $\mathrm{mL}$ concentrations, with fish food solution $(0.3 \mathrm{mg}$ per 
larva) in accordance with the procedure described by Cabral (Cabral et al., 2009). Individualized $A$. aegypti L3 larvae (F1-F5) (20 larvae per group) were evaluated in triplicate. There were again two control groups: one with acetone solution (without grandisin) and another with untreated solution. The larvae were maintained in a climate-controlled chamber at $27 \pm 1{ }^{\circ} \mathrm{C}, 70 \pm 10 \%$ relative humidity and $12 \mathrm{~h}$ photoperiods and LC50 were analyzed using Spearman-Karber analysis (Hamilton et al., 1978).

The digestive system histology were carried out using L3 larvae (treated, control and acetone control) fixed in $2.5 \%$ glutaraldehyde in sodium cacodylate buffer (0.1 M, pH 7.2) for $4 \mathrm{~h}$. They were then dehydrated with increasing concentrations of ethanol (70, 80, 90, 96 and $100 \%$ ), through immersion in each of these solutions for 15 min. Next, they were embedded in historesin JB4 and the resultant blocks were sliced using a microtome to obtain a series of sections of $3 \mu \mathrm{m}$ in thickness. These sections were stained using the hematoxylin-eosin technique and the slices thus obtained were examined and photographed using an optical microscope (Bancroft \& Stevens, 1996).

The cytotoxicity bioassays were carried out using peritoneal macrophage cells from BALB/c mice. The cells were isolated from the animals' peritoneal and were kept in a culture media consisting of $0.1 \mathrm{~mL}$ RPMI 1640 supplemented with 1 mmol 1-1 HEPES, penicillin G (10 $\left.{ }^{5} \mathrm{IU} 1: 1\right)$ and streptomycin sulfate (10 g 1:1). In all the assays, peritoneal macrophage cells were used at a concentration of $2 \times 10^{5} / \mathrm{mL}$ in each well of 96-well plates. After $2 \mathrm{~h}$ of incubation at $37{ }^{\circ} \mathrm{C}$ under $5 \% \mathrm{CO}_{2}$, the cells were washed twice with RPMI, to remove nonadhering cells. The grandisin lignan was added to the cell cultures at a standard toxic concentration of $160 \mu \mathrm{g} / \mathrm{mL}$, corresponding to $200 \mu \mathrm{M}$, and then incubated for $24 \mathrm{~h}$ at $37{ }^{\circ} \mathrm{C}$ under $5 \% \mathrm{CO}_{2}$, in accordance with the procedure described by Sauvain et al. (1993).

The assays were based on tetrazolium (MTT) [3-(4,5-dimethylthiazol-2-yl)-2,5-diphenyltetrazolium bromide], which is a fast colorimetric assay commonly used to determine cell proliferation and viability (Mosmann, 1983). After $4 \mathrm{~h}$ of incubation, the supernatant was discarded and DMSO was added to dissolve the formazan that had been precipitated. The absorbance was read in a spectrophotometer at $490 \mathrm{~nm}$, with untreated cells taken to represent $100 \%$ viability (AndrighettiFrohner et al., 2003). The cytotoxicity of the compound was calculated as follows:

$$
\text { Viable cells }=\frac{\text { Average absorbance of each compound concentration }}{\text { Average absorbance of control }} \times 100
$$

The lethal concentration 50\% (LC50) was defined as the concentration causing $50 \%$ cell death. The percentage of macrophage lysis was determined in triplicate.

\section{Results}

A. aegypti (larvae L3) grandisin treated interfered with the development of larvae at stages L3-L4 and with development from larvae to adults. The grandisin caused $79 \%(13,6 \pm 2,08, p \leq 0,001)$ larval (L3) mortality at $200 \mu \mathrm{g} /$ $\mathrm{mL}$ and $50 \%$ of the larvae died within $24 \mathrm{~h}$ of the treatment, while the remaining larvae survived for up to $192 \mathrm{~h}$, with LC50 $150 \mu \mathrm{g} / \mathrm{mL}$. Mortality was not observed in acetone control solution (without grandisin) and untreated solution. The lignan showed $36 \%(36 \pm 0,009)$ toxicity on macrophages at LC50/24h $160 \mu \mathrm{g} / \mathrm{mL}$ when compared acetone control solution $(1 \pm 0,002)$ and DMSO control solution $(1 \pm 0,002)$ at LC50/24 h $190 \mu \mathrm{g} / \mathrm{mL}$ and LC50 32 $\mu \mathrm{g} / \mathrm{mL}$, respectively. Histological analysis on $A$. aegypti larvae treated with grandisin (LC50) showed changes in the intestine, specifically the level in the anterior-middle midgut (Figure 3B), in which intense tissue destruction and cell disorganization were observed. Most cells in this region showed extensive vacuolization in the cytoplasm. Some cells showed absence of cytoplasmic boundaries (Figure 3C). The larvae of the control groups and acetone control had digestive tract cells with a normal appearance and without morphological changes (Figures $1 \mathrm{C}$ and 2B). They showed well-preserved epithelium with a basal membrane and a muscle layer (Figure 2D). The epithelial cells were seen to be arranged in a single layer of low cylindrical cells and the apical surface covered with microvilli. Malpighian tubules showing cellular disruption (Figure 3B) and neither was the muscle tissue, in which no effect was observed with grandisin, either in the treated groups or in the control groups (Figures 3B and 2D).

\section{Discussion}

The A. aegypti mortality after treatment with the lignan grandisin (1) isolated from $P$. solmsianum was corroborated through findings using extracts from Piper species against the larvae of Alabama argillacea (Lepidoptera: Noctuidae) (Miranda et al., 2002). Previous studies on treatment of L1 larvae of $A$. aegypti with grandisin showed $100 \%$ larval mortality at $100 \mu \mathrm{g} / \mathrm{mL}$ concentration (Cabral et al., 2009). Additionally, 100\% mortality was also observed with the lignan, on thirdinstars larvae (L3) at $>200 \mu \mathrm{g} / \mathrm{mL}$ concentrations.

The toxic effect of grandisin on the larvae of $A$. aegypti observed in the anterior-median midgut corroborate the initial observation of changes to the midgut of $A$. aegypti when exposed to treatment with plant extracts (Arruda et al., 2003a). The peritrophic membrane of larvae treated with grandisin continued to present a normal appearance, in contrast to the greater 


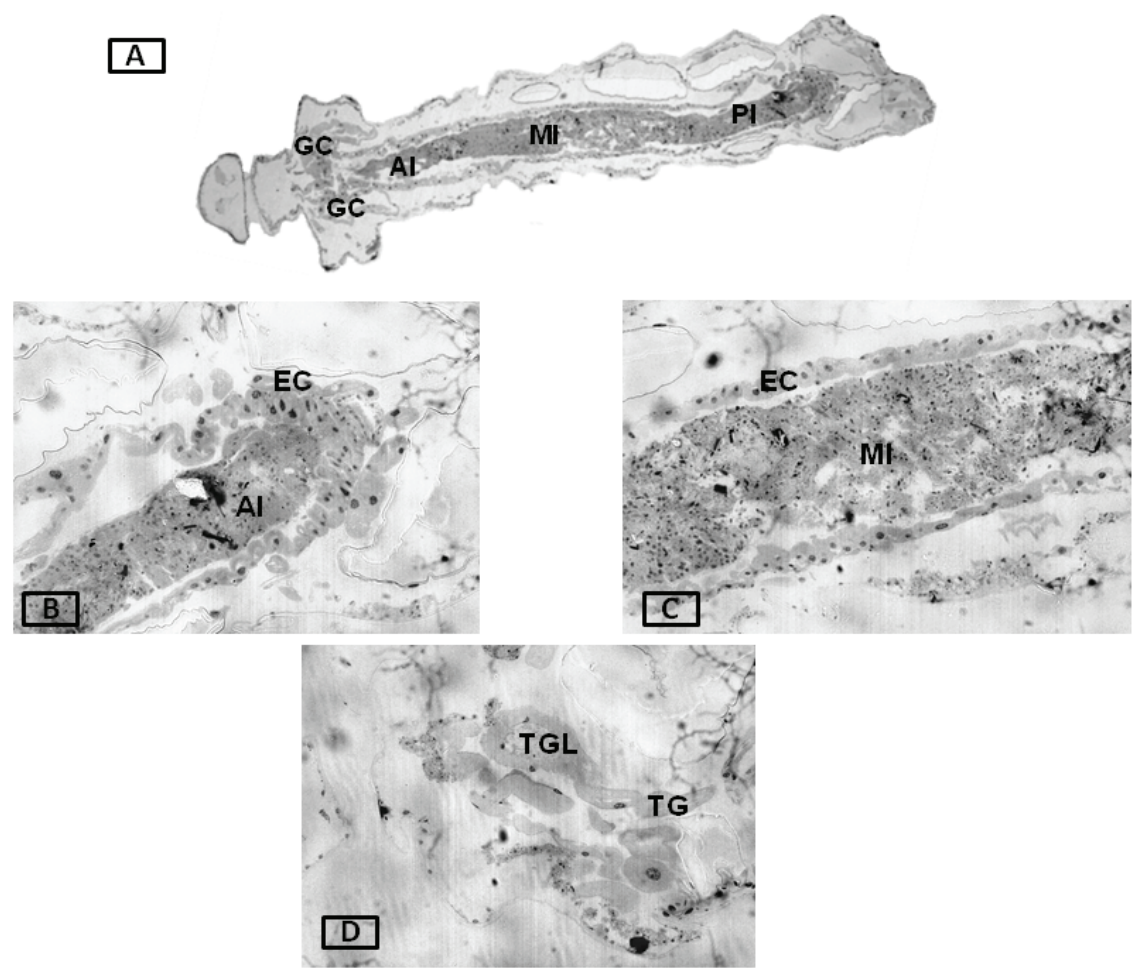

Figure 1. Photomicrographs of the digestive tract of L3 larvae of A. aegypti in the control group maintained with food, stained with HE, longitudinal section. A. Overview; gastric caeca (GC), anterior intestine (AI), midgut (MI), hindgut (PI) 10x; B. Details of the anterior intestine (AI) showing intestinal epithelial cells (EC) 20x. C. Midgut (MI) and intestinal epithelial cells (EC) 20x; D. Details of the Malpighian tubules (MT) and lumen of the Malpighian tubule (TGL) 20x.

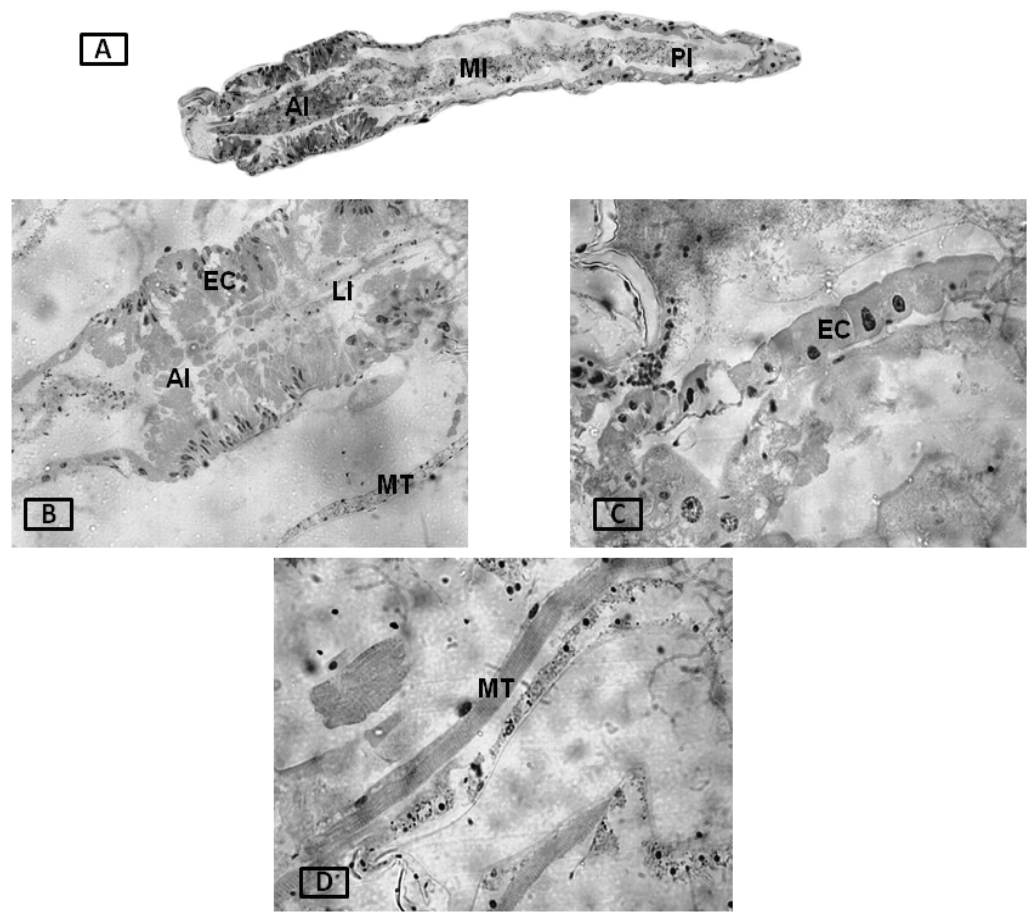

Figure 2. Photomicrographs of the digestive tract of L3 larvae of A. aegypti in the control acetone group maintained with food, stained with HE, longitudinal section. A. Overview. Anterior intestine (AI), midgut (MI), hindgut (PI). B. Details of the anterior intestine (AI) showing lumen of the intestine (LI), intestinal epithelial cells (EC), and muscle tissue (MT); C. Details of the posterior intestine cells (EC) 40x. D. Details of the muscle tissue (MT) 4x. 

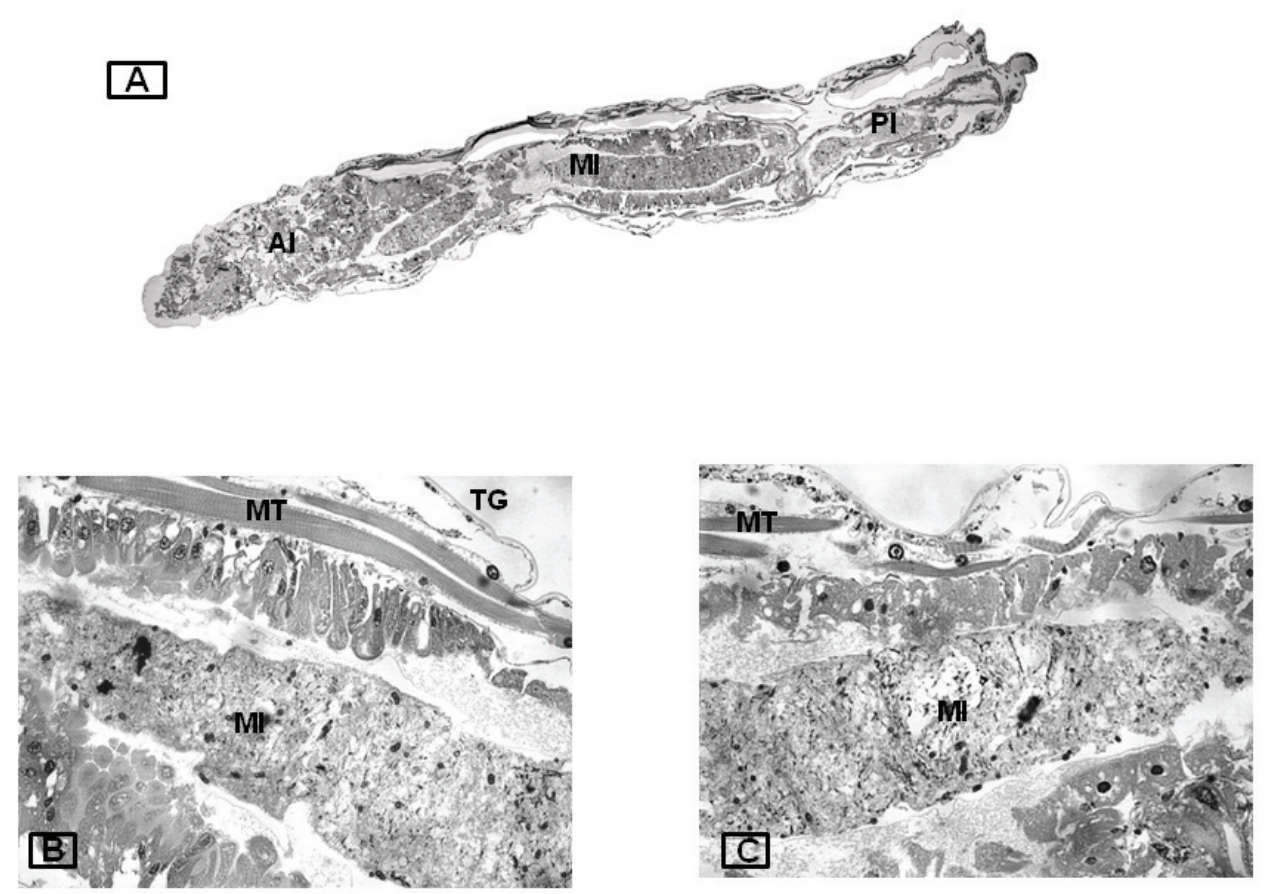

Figure 3. Photomicrographs of the digestive tract of L3 larvae of $A$. aegypti in the grandisin test group maintained with food, stained with HE, longitudinal section. A. Overview. B. Anterior intestine (AI), midgut (MI), hindgut (PI) 10x. C. Details of the midgut (MI) showing muscle tissue (MT) and Malpighian tubules (TG) 20x.

effect on peritrophic membrane thickness in $A$. aegypti when treated with extracts of Magonia pubescens (Arruda et al., 2003b). The cell destruction in A. aegypti began in the anterior midgut and ended in the middle, but without reaching the posterior intestine. These data suggest that there is a gradual process of tissue destruction, possibly related to the duration of exposure of larvae to grandisin. In conclusion, this study clearly illustrated the efficacy of the lignan grandisin, with potential for use against $A$. aegypti larvae.

\section{Acknowledgments}

This research was supported by grants from Fundação de Amparo a Pesquisa do Estado do Rio de Janeiro, Fundação de Amparo a Pesquisa do Estado de São Paulo Conselho Nacional de Desenvolvimento Científico e Tecnológico and Fundação para o Desenvolvimento Científico e Tecnológico em Saúde.

\section{References}

Andrighetti-Frohner CR, Antonio RV, Creczynski-Pasa TB, Barardi CRM, Simões CMO 2003. Citotoxicity and potential antiviral evaluation of violacein produced by Chromobacterium violaceum. Mem I Oswaldo Cruz 98: 843-848.
Arruda W, Oliveira GMC, Silva IG 2003 a. Alterações morfológicas observadas em larvas de Aedes aegypti (Linnaeus, 1762) submetidas à ação do extrato bruto etanólico da casca do caule da Magonia pubescens. Entomol Vectores 10: 47-60.

Arruda W, Oliveira GMC, Silva IG 2003 b. Toxicidade do extrato etanólico de Magonia pubescens sobre larvas de Aedes aegypti. Rev Soc Bras Med Trop 36: 17-25.

Bancroft JD, Stevens A 1996. Theory and practice of histological techniques. Edinburgh: Churchill Livingstone.

Cabral MMO, Azambuja P, Gottlieb OR, Garcia ES 2000a. Effects of some lignans and neolignans on the development and excretion of Rhodnius prolixus. Fitoterapia 71: 1-9.

Cabral MMO, Kollien AH, Kleffmann T, Azambuja P, Gottlieb OR, Garcia ES, Schaub GA 2000b. Rhodnius prolixus: effects of the neolignan burchellin on in vivo and in vitro diuresis. Parasitol Res 86: 710-716.

Cabral MMO, Azambuja P, Gottlieb OR, Kleffmann T, Garcia ES, Schaub GA 2001. Burchellin: effects on Triatoma infestans and on Trypanosoma cruzi within this vector. Parasitol Res 87: 730-735.

Cabral MMO, Alencar JA, Guimarães EA, Kato MJ 2009. Larvicidal activity of grandisin against Aedes aegypti. J Amer Mosq Control Assoc 25: 103-105.

Consoli RAGB, Oliveira RL 1994. Principais Mosquitos de 
Importância Sanitária no Brasil. Rio de Janeiro: Editor Fiocruz.

Hamilton MA, Russo RC, Trurston RV 1978. Trimmed spearman-karber method for estimating median lethal concentrations in toxicity bioassays. Environ Sci Technol 12: 714-719.

Holloway D, Scheinmann F 1974. Extractives from Litsea species. 2. 2 Lignans from Litsea grandis and Litsea gracilipes. Phytochemistry 13: 1233-1236.

Kato MJ, Furlan M 2007. Chemistry and evolution of Piperaceae. Pure Appl Chem 79: 529-538.

Lopes NP, Albuquerque S, Kato MJ, Yoshida M 1998. Flavonoids and lignans from Virola surinamensis twigs and there in vitro activity against Trypanosoma cruzi. Planta Med 64: 667-669.

Martins RCC, Latorre JR, Sartorelli P, Kato MJ 2000. Phenylpropanoids and tetrahydrofuran lignans from Piper solmsianum. Phytochemistry 55: 843-846.

Martins RCC, Lago JH, Albuquerque S, Kato MJ 2003. Trypanocidal tetrahydrofuran lignans from inflorescences of Piper solmsianum. Phytochemistry 64: 667-670.

Miranda Oliveira JEM, Rocha KCG, Bortoli SA, Navickiene HMD, Kato MJ, Furlan M 2002. Potencial inseticida do extrato de Piper tuberculatum (Piperaceae) sobre
Alabama argillacea (Huebner, 1818) (Lepidoptera: Noctuidae). Rev Bras Ol Fibrosas 6: 557- 563.

Mosmann T 1983. Rapid colorimetric assay for cellular growth and survival. J Immunol Methods 65: 55-63.

Nogueira CDR, Mello RP, Kato MJ, Cabral MMO 2009. Disruption of Chrysomya megacephala growth caused by lignan grandisin. J Med Entomol 46: 281-283.

Quijano-Abril MA, Callejas-Posada R, Miranda-Esquivel DR 2006. Areas of endemism and distribution patterns for Neotropical Piper species (Piperaceae). J Biogeogr 33: 1266-1278.

Sauvain M, Dedet JP, Kunesch N, Poisson J, Gantier JC, GairalP, Kunesch G 1993. In vitro and in vivo leishmanicidal activities of natural and synthetic quinoids. Phytother Res 7: 167-171.

\section{*Correspondence}

\section{Marise M. O. Cabral}

Laboratório de Insetos Vetores/CECETEN, Unidade de Ensino, Pesquisa e Extensão Professor Antonio Orlando Izolani, Universidade Severino Sombra

Av. Exp. Oswaldo de Almeida Ramos, 280, Centro, 27700-00

Vassouras-RJ, Brazil

mmaleck@uss.br

Tel: +55242471 8371 